\title{
SUBYEKTIVITAS AUDITOR JUDGMENTS SEBAGAI BAGIAN DARI PROFESIONALISME
}

\author{
Ade Irma Hidayah \\ Pasca Sarjana Fakultas Ekonomi dan Bisnis Universitas Brawijaya Malang \\ Jl. Mayjen Haryono 165 Malang; Telp. 081332729936 \\ adeirma.hidayah@gmail.com
}

Abstract

This paper attempts to provide a descriptive explanation of auditor' judgments as a part of audit process. By using information from research and her personal experiences, the author provide a different way to understand the nature of auditor' subjectivity. According to standards established by Institute of Certified Public Accountant, auditor is required to perform audit using his/ her professional judgment. The word "professional judgments" appear in every chapter of this standard. Auditor 'opinion is expected to be objective and free from personal auditor' subjectivity. Although, the "judgment" is very closely related to ideas, calculation and even the result of contemplation. Behind the screen of judgment making could not be separated from the condition of auditor. There is no perfection objectivity in a judgment. Therefor, subjectivity in audit judgment are necessity. However, judgment based on knowledge, experience, morality, common sense and conscience is accountable judgment.

Keywords: auditor judgments, audit proses, profesional judgments

Abstrak

Artikel ini mencoba memberikan paparan deskriptif tentang pertimbangan auditor sebagai salah satu bagian tidak terpisahkan dari proses audit. Dengan mengkombinasikan kesimpulan dari hasil-hasil penelitian dengan praktik di lapangan yang dialami penulis sebagai seorang auditor. Dalam Standar Profesional Akuntan Publik (SPAP) seorang auditor diwajibkan untuk melaksanakan audit dengan menggunakan pertimbangan profesionalnya. Kata "pertimbangan 
profesional" muncul hampir di seluruh PSA dalam SPAP. Opini yang dibuat oleh auditor diharapkan bersifat obyektif dan lepas dari subyektifitas pribadi auditor yang bersangkutan. Namun kata pertimbangan sangat erat hubungannya dengan hasil pemikiran, hasil perhitungan dan bahkan hasil perenungan. Dari sesuatu yang sifatnya konkret dan riil hingga sesuatu yang bersifat abstrak. Dari hal yang objektif sampai subyektifitas dari pembuat pertimbangan akan menyertai proses mempertimbangkan.

Kata kunci: pertimbangan auditor, proses audit, pertimbangan profesional

\section{PENDAHULUAN}

Tidak ada kesempurnaan obyektifitas dalam sebuah pertimbangan. Sehinggan sebuah subyektifitas dalam pertimbangan audit adalah keniscayaan. Namun pertimbangan yang didasarkan pada pengetahuan, pengalaman, moralitas, akal sehat dan hati nurani yang luhur merupakan sebuah pertimbangan yang bisa dipertanggungjawabkan.

\section{Simbiosis Mutualisme Auditor-Klien}

Apa yang terjadi jika profesi Anda mempengaruhi kesuksesan orang lain dan pada saat yang bersamaan orang lain tersebut juga mempengaruhi kesuksesan profesi Anda? Tepat sekali, keduanya memiliki ketergantungan satu sama lain atau bisa dikatakan bersimbiosis mutualisme. Kira-kira seperti itulah peneliti menganalogikan hubungan antara auditor dan klien. Profesi sebagai auditor memang tidak bisa dilepaskan dari manajemen suatu entitas sebagai konsumennya. Manajemen membutuhkan opini auditor sebagai upaya untuk meningkatkan kepercayaan pihak stakeholder terhadap laporan keuangan yang telah mereka susun.

Dalam kerangka teori keagenan, perusahaan dipandang sebagai wujud dari rangkaian kontrak yang tidak selamanya tertulis (nexus of contract) (Eisenhardt, 1989). Kontrak dimaksud terjadi di antara berbagai pihak atau konstituen yang masing-masing mempunyai kepentingan sendiri dan memiliki potensi saling bertentangan atau konflik. Dalam teori ini, paling tidak dua pihak dapat diidentifikasikan, yaitu pertama, pihak yang mempercayakan sumber daya atau modal yang dimilikinya kepada pihak lain, yang disebut sebagai prinsipal. Sedangkan pihak yang kedua adalah pihak yang menerima sumber daya dari pihak pertama (prinsipal) untuk dikelola bagi kepentingan pemiliknya. Pihak yang kedua ini dinamakan sebagai agen yang pada dasarnya diperankan oleh direksi dan manejemen suatu organisasi. Prinsipal tentu saja ingin memastikan bahwa pihak agen bertindak mengelola sumber daya yang dipercayakan kepadanya seoptimal mungkin bagi kepentingan prinsipal. Namun, prinsipal harus menerima kenyataan bahwa ia tidak mungkin memantau dan mengendalikan secara langsung dan penuh tindakan-tindakan sang agen. Karena 
itu, prinsipal menginginkan suatu mekanisme yang praktis dan efisien untuk mewujudkan fungsi pemantauan dan pengendalian itu (monitoring problem). Shapiro (2005) menjelaskan bahwa adanya perbedaan tujuan antara principal dan agen dapat diatasi dengan adanya monitoring dengan menggunakan jasa audit.

Sementara itu, pihak agen berada di posisi yang selalu dicurigai akan menyalahgunakan sumber daya yang dipercayakan kepadanya, walaupun di sisi lain ia berkepentingan untuk meyakinkan prinsipal bahwa kenyataannya tidak akan selalu demikian. Selain itu, pihak agen secara rasional ingin menunjukkan dirinya sebagai agen yang bereputasi atau berkinerja baik sehingga ia akan memperoleh label harga yang tinggi di pasar tenaga kerja. Namun, agen menyadari bahwa diperlukan mekanisme yang praktis dan relatif murah untuk mengkomunikasikan komitmen dan kinerjanya kepada prinsipal. Dalam kerangka teori keagenan inilah auditing muncul sebagai salah satu solusi yang optimal untuk meningkatkan tingkat kepencayaan principal terhadap agen.

Tidak hanya klien yang membutuhkan jasa auditor, auditor, sebagai penyedia jasa tidak berbeda dengan penyedia jasa lainnya, juga membutuhkan klien untuk menjalankan usahanya. No client no money. Ketika dua pihak memiliki ketergantungan satu sama lain, maka akan ada upaya keduanya untuk menjaga hubungan agar tetap baik. Auditor misalnya, mereka berharap bahwa pada masa- masa mendatang auditee akan tetap menggunakan jasanya. Profesi auditor bukanlah profesi tunggal seperti bidan yang buka praktek di rumah. Profesi ini melibatkan suatu entitas bisnis yang disebut Kantor Akuntan Publik (KAP) yang di dalamnya terdapat karyawan yang membantu partner melakukan audit. Biaya-biaya yang dikeluarkan KAP untuk menggaji karyawan dan biaya operasional kantor tidaklah kecil. ExManager PwC Jakarta yang sekarang menjadi Senior Tax Manager di Coca-Cola Bottling Indonesia (Meisje A. Tombokan) mengkritik salah seorang partner $\mathrm{PwC}$ yang memilih resign dan mendirikan KAP sendiri sebab partner tersebut harus "jualan" untuk membangun KAP barunya. Untuk menghidupi KAP seorang partner memang perlu "mempromosikan" KAP-nya. Apalagi KAP lokal, kecil, dan baru lahir. Ibarat air mineral kemasan bukan "aqua" tentu saja butuh upaya keras untuk mendapat dan mempertahankan klien. Mereka akan memaknai klien sebagai asset berharga yang akan dijaga sedemikian rupa dan jangan sampai lepas. Penelitian Iyer dan Rama (2004) menyatakan bahwa pentingnya klien bagi KAP berpengaruh positif dan signifikan terhadap keinginan klien untuk mempengaruhi kebijakan audit. Ini berarti bahwa para klien meyakini bahwa mereka (klien) lebih besar kemungkinannya untuk dapat mendesak auditor jika bisnis mereka dianggap sangat penting bagi KAP.

Namun tidak hanya klien yang memiliki arti besar bagi KAP. Auditeepun memandang KAP sebagai bagian yang penting bagi kelancaran proses bisnisnya. Apalagi pada era sekarang ini, pengajuan hutang ke bank butuh laporan keuangaan audited, pengajuan tender harus audited, pengajuan penundaan pita cukai harus audited, dan masih banyak lagi pengajuan yang harus disertai dengan laporan 
keuangan yang telah diaudit. Bahkan sebagian besar mensyaratkan opini audit haruslah wajar tanpa pengecualian atau unqualified. Tentu saja auditee berharap bahwa auditor bisa memberikan opini unqualified yang merepresentasikan bahwa laporan keuangan yang mereka susun telah bebas dari salah saji yang material. Jika opini yang dikeluarkan oleh auditor sampai memberikan opini tidak wajar, maka manajemen perusahaan akan berada bagai "ancik-ancik pucuke eril". Kredit yang sedang dalam proses underwriting terancam ditolak, kantor pajak kemungkinan besar akan mengirimkan surat pemeriksaan.

Keinginan besar dari klien yang dalam hal ini adalah agen untuk memperoleh opini yang baik dari auditor dan kenyataan bahwa auditor adalah watchdog menempatkan auditor dalam dilema etis. Hal tersebut diperkeruh ketika klien memiliki integritas moral yang rendah. Kaplan (2001) menyatakan bahwa nilai moral yang rendah dari klien akan meningkatkan risiko audit bagi auditor sebagai akibat tingginya probabilitas klien melakukan kecurangan. Hubungan simbiosis mutualisme inilah yang kerap menimbulkan dilema etis auditor yang dampaknya mungkin saja menyebabkan kecurangan yang dilakukan auditor untuk mendukung kepentingan agen. Hal itu jelas tidak selaras dengan tujuan general audit yaitu menyatakan pendapat atas kewajaran laporan keuangan.

\section{Auditor Sebagai Profesi Penting}

Walaupun laporan keuangan bukanlah satu-satunya alat yang digunakan oleh stakeholder dalam proses pengambilan keputusan, namun laporan keuangan merupakan bagian yang penting dalam proses tersebut. Tindakan yang didasarkan pada informasi selalu mempunyai sisi risiko, karena informasi yang digunakan mungkin mengandung kekeliruan. Risiko dapat berupa adverse selection ataupun moral hazard (Arens and Loebbecke, 2000). Sebelum terbit Securities Act 1933 dan Securities Exchange Act 1934, emiten di pasar modal Amerika Serikat bebas untuk dilakukan atau tidak dilakukan audit terhadap laporan keuangannya. Dua undang-undang tersebut yang kemudian menetapkan keharusan laporan keuangan perusahaan emiten dilakukan audit oleh auditor independen. Manfaat audit tersebut tentu saja untuk melindungi partisipan pasar modal di AS, terutama para investor, serta pihak pemerintah yang bertanggung jawab untuk mencegah tipu-menipu dalam dunia bisnis.

Auditor merupakan "watchdog" bagi pihak-pihak yang berkepentingan terhadap kegiatan organisasi bisnis maupun akibat kegiatan yang dilakukannya, namun tidak memiliki kewenangan langsung untuk menguji apakah informasi tentang halhal yang dilakukan oleh organisasi bisnis itu sudah betul dan sesuai dengan ketentuan yang ada. Hal ini sekaligus mempertegas adanya fungsi audit dalam masyarakat (fungsi sosial), dan karenanya auditor seyogyanya mengemban amanat itu dengan penuh tanggung jawab. Bahkan di AS dalam beberapa dekade terakhir, muncul ungkapan "auditor-as-guarantor concept" dan "deep-pocket hypothesis". 
Maksudnya adalah bahwa auditor makin lama makin diposisikan oleh pasar sebagai tempat memperoleh ganti rugi yang terakhir, apabila ganti rugi dari pihak lain sudah tidak mungkin lagi.

Begitu besar harapan stakeholder terhadap profesi ini sebagai tempat memperoleh ganti rugi yang terakhir, apabila ganti rugi dari pihak lain sudah tidak mungkin lagi. Namun tidak semua auditor menyadari betapa penting profesinya. Menurut Mautz dan Sharaf (1993), sebetulnya jika profesi auditor berani dengan jelas menerima kewajiban sebagaimana yang diharapkan oleh masyarakat dan sepenuhnya masuk dalam wilayah tanggung jawabnya, maka peranan profesi ini dalam masyarakat menjadi semakin jelas. Kejelasan itu dapat diibaratkan dengan penerimaan tanggung jawab untuk pengobatan penyakit oleh profesi kedokteran atau tanggung jawab mengungkapkan kriminal oleh profesi kepolisian.

Bagi kedua profesi itu berlaku pula standar-standar internal yang dikembangkan sendiri untuk pelaksanaan fungsinya. Namun, tidak ada alasan bagi kedua profesi itu untuk menyatakan kegagalan dalam pengobatan atau pengungkapan kejahatan sebagai hal di luar tanggung jawabnya hanya karena standar internal yang berlaku telah dipenuhinya. Dengan kata lain, masyarakat mengharapkan jasa pengungkapan kesalahan informasi dari profesi auditing, sebagaimana pula mereka mengharapkan pengobatan atau pengungkapan kejahatan dari dokter atau polisi, bukan sekadar jasa pemenuhan tuntutan standar. Dengan kata lain, auditor dituntut untuk memberikan nilai lebih dari suatu laporan dengan mengedepankan integritas yang tinggi terhadap profesinya.

Kasus kegagalan audit berskala besar yang terjadi di Amerika Serikat, seperti kasus yang menimpa Enron, telah menimbulkan kembali skeptisisme masyarakat mengenai ketidakmampuan profesi akuntan dalam menjaga independensi. Di luar AS terjadi kasus Enron - Arthur Anderson dan Word.Com - Arthur Anderson. Enron, perusahaan raksasa di bidang energi dengan omzet US\$ 100 milyar pada tahun 2000, secara mendadak mengalami kebangkrutan dan meninggalkan hutang hampir sebesar US\$ 31,2 milyar. Kasus tersebut melibatkan Arthur Anderson, salah satu dari big five Certified Public Accountant (CPA) firm, yang mengaudit laporan keuangan Enron (Wikipedia). Bagaimana mereka sampai tidak mengetahui adanya material misstatement dalam laporan keuangan Enron selama bertahun-tahun.

Sebetulnya fungsi auditor KAP adalah bukan hanya menentukan bahwa laporan keuangan telah disajikan sesuai dengan SAK yang berlaku umum, tetapi juga memberikan gambaran yang objektif dan akurat kepada investor maupun kreditor mengenai apa yang terjadi di perusahaan. Dalam kedua hal ini Arthur Anderson dianggap gagal. Kegagalan tersebut memiliki implikasi yang besar terhadap pengguna laporan keuangan. Satu dampak yang sangat jelas pada saat kasus Enron yaitu para investor yang merugi karena nilai saham Enron yang ambruk sangat dramatis. Hal tersebut disebabkan manajemen Enron yang telah melakukan window dressing dengan memanipulasi angka-angka laporan keuangan agar kinerjanya tampak baik. 
Bahkan, pendapatan di-mark-up sebesar US\$ 600 juta, dan utang senilai US\$1,2 miliar disembunyikan dengan teknik off-balance sheet. Kejadian-kejadian tersebut menyebabkan timbulnya keraguan atas integritas auditor KAP. Bahkan penelitian Cullinan (2004) dalam Johari, Sanusi, Rahman dan Omar (2010) membuktikan bahwa publik menuntut auditor untuk memiliki tanggung jawab moral dalam melakukan pekerjaan mereka.

Profesi auditor bukanlah profesi yang bebas dari aturan. Dalam standar umum jelas disebutkan bahwa seorang auditor haruslah seseorang yang independen, memiliki keahlian cukup dan menggunakan kemahiran profesional. Namun pada kenyataannya hal tersebut kadang tidak dilaksanakan dengan benar. Hal tersebut tidak lepas dari multifungsinya profesi auditor. Selain diijinkan untuk memberikan jasa auditing yang merupakan bagian dari assurance services, auditor juga diperbolehkan untuk memberikan jasa assurance lainnya seperti penyusunan laporan keuangan, evaluasi keandalan sistem informasi, atau menilai kecukupan dari sistem untuk mengelola risiko bisnis, bahkan menilai efektifitas dari sistem pengukuran kinerja klien. Banyaknya jasa assurance yang bisa diberikan oleh auditor, menempatkan auditor menjadi sebuah profesi penting, namun juga sulit untuk berada pada posisi independen.

Auditor berada pada dua kepentingan besar perusahaan sebagai agent dan shareholder sebagai principal. Maksudnya adalah bahwa assurance service fungsi seorang auditor adalah untuk meningkatkan kualitas informasi bagi para pengambil keputusan, dan menyangkut keandalan sistem informasi, kecukupan sistem manajemen risiko, efektifitas sistem pengukuran kinerja, dan kecukupan keamanan dari transaksi komersial. Dalam jasa atestasi, auditor memberikan opini mengenai keandalan asersi manajemen, yang menyangkut: asersi mengenai pengendalian intern, asersi mengenai ketaatan terhadap unsur-unsur dalam perjanjian, dan asersi mengenai ketaatan terhadap undang-undang dan peraturan yang berlaku. Sedangkan dalam auditing, auditor memberikan pernyataan mengenai kewajaran dari penyajian laporan keuangan (Konrath, 2002:4).

Auditor memang tidak diijinkan untuk memberikan jasa auditing dan jasa atestasi lainnya untuk satu klien yang sama dalam periode yang sama pula. Hal tersebut jelas berkenaan dengan independensi. Namun pada kenyataannya hal tersebut tetap saja terjadi, meski pada prakteknya dilakukan secara sembunyi-sembunyi. Hel tersebut memang tidak dapat dilepaskan dari tekanan pasar, baik ditinjau dari konsumen maupun kompetitor. Klien mengharapkan one stop services dan competitor sesama auditor mampu bemberikannya. Auditor seakan dipaksa untuk menyerah pada kondisi pasar. Pertanyaan utama adalah apakah standar umum telah cukup untuk mengatasi fenomena tersebut? Tampaknya hal yang demikian dibiarkan berjalan begitu saja dan seakan-akan hanya menunggu niat baik para praktisi untuk tidak melanggar standar. 


\section{Celah Profesional}

Dalam melaksanakan pekerjaannya auditor harus mematuhi standar auditing. Dalam SA 110 SPAP disebutkan bahwa auditor bertanggung jawab untuk merencanakan dan melaksanakan audit untuk memperoleh keyakinan memadai tentang apakah laporan keuangan bebas dari salah saji material, baik yang disebabkan oleh kekeliruan atau kecurangan (IAPI, 2011). Dalam hal ini posisi auditor berseberangan dengan kepentingan manajemen yang cenderung menginginkan opini unqualified. Masalah biasanya tidak akan timbul jika tidak terdapat salah saji yang material dalam laporan keuangan klien. Namun jika klien dengan sengaja dan tujuan tertentu melakukan kesalahan saji dan sifatnya material dan hal itu terdeteksi oleh auditor, maka adjustment akan diajukan oleh auditor. Penolakan klien atas adjustment auditor adalah hal yang biasa terjadi dan hal ini (jika sifatnya material) akan mempengaruhi opini.

Tidak sedikit klien yang merasa tidak nyaman atas adjustment atau bahkan opini yang bukan wajar tanpa pengecualian dan akhirnya memutuskan untuk tidak menggunakan jasa KAP tersebut pada tahun-tahun berikutnya. Hal semacam ini tentu saja tidak menguntungkan bagi KAP dan auditor. Disinilah dilema itu terjadi, di satu sisi auditor berusaha menjalankan profesinya sesuai dengan standar yang ada, dan di sisi lain auditor harus mempertahankan klien agar tidak berpindah KAP. Beberapa skandal akuntansi besar yang terjadi di Amerika Serikat seperti kasus Enron - Arthur Anderson dan WorlComm - Arthur Anderson, sedikit banyak juga dilatarbelakangi dilema auditor ini. Jika KAP besar dan multinasional sekelas Arthur Anderson saja bisa terjebak dalam situasi ini apalagi KAP kecil, lokal dan baru lahir yang sangat membutuhkan keberadaan klien untuk ke going concern-nan KAP, akan sangat rentan untuk melakukan kolusi dengan klien.

Mengapa auditor memiliki ruang gerak yang cukup luas untuk melakukan kolusi dengan klien? Mungkin ada banyak kata dan kalimat yang siapa saja bisa ungkapkan untuk menjawab pertanyaan di atas. Namun dalam tulisan ini penulis ingin mengangkat satu kata yang sering sekali muncul dalam standar auditing dan bahkan muncul hampir di setiap PSA, kata tersebut adalah "pertimbangan auditor". Standar memberikan keleluasaan kepada auditor untuk menggunakan pertimbangan profesionalnya guna memutuskan opini yang dibuatnya. SA Seksi 411 (IAPI, 2011) yang mengatur tentang makna frasa menyajikan secara wajar sesuai dengan prinsip akuntansi yang berlaku umum di Indonesia misalnya, dalam paragraf 4 dijelaskan bahwa pendapat auditor tentang kewajaran posisi keuangan, hasil usaha, dan arus kas sesuai dengan prinsip akuntansi yang berlaku umum di Indonesia harus didasarkan atas pertimbangannya apakah: (a) prinsip akuntansi yang dipilih dan diterapkan telah berlaku umum di Indonesia, (b) prinsip akuntansi yang dipilih tepat untuk keadaan yang bersangkutan, (c) laporan keuangan beserta catatannya memberikan informasi cukup yang dapat mempengaruhi penggunaan, pemahaman, dan 
penafsirannya, (e) laporan keuangan mencerminkan peristiwa dan transaksi yang mendasarinya dalam suatu cara yang menyajikan posisi keuangan, hasil usaha, dan arus kas dalam batas-batas yang dapat diterima, yaitu batas-batas yang layak dan praktis untuk mencapai laporan keuangan.

Kata pertimbangan sangat erat hubungannya dengan hasil pemikiran, hasil perhitungan dan bahkan hasil perenungan. Dari sesuatu yang sifatnya konkret dan riil hingga sesuatu yang bersifat abstrak. Dari hal yang objektif sampai subyektifitas dari pembuat pertimbangan akan menyertai proses mempertimbangkan ini. Istilah "pertimbangan" memang sangat populer di antara auditor, dan memang harus diterima sebagai salah satu ciri yang inherent dengan hampir setiap profesi. Namun istilah pertimbangan profesi ini sekaligus pula mengandung bahaya, terutama kalau digunakan sembarangan atau digunakan sekadar sebagai senjata pelindung. Istilah professional judgment sesungguhnya berhubungan erat dengan kemampuan yang dituntut dari auditor untuk merangkai langkah-langkah serta hasil-hasil yang diperolehnya menuju pada simpulan menyeluruh. Luasnya ruang lingkup dari pertimbangan auditor ini membuat nilai subyektivitas begitu kuat terhadap hasil pertimbangan. Pertimbangan auditor yang satu dengan yang lainnya menjadi sangat beragam untuk satu klien dan satu area yang sama. Pertimbangan auditor tidak sama dengan rasio keuangan yang memiliki rumus pasti. Terlebih lagi pertimbangan yang satu akan mempengaruhi pertimbangan lainnya pada proses audit. Sebagai contoh pertimbangan atas risiko akan mempengaruhi pertimbangan tentang materialitas dan tentu saja akan berpengaruh pada pemberian opini. Suatu hal yang subyektif didasarkan pada hal subyektif pula, kemungkinan akan menghasilkan sesuatu yang sifatnya subyektif. Auditor bisa saja mengatakan bahwa mereka memiliki kesepakatan bersama tentang cara penilaian tinggi rendahnya risiko. Namun makna tinggi, rendah dan sedang itu sendiri tidak bisa didefinisikan secara kongkret dan tidak memiliki ukuran yang pasti.

Menurut Manao (2007) pembentukan judgment memerlukan disiplin mental yang kuat dan ketat sehingga tidak dijadikan alasan untuk menggampangkan pelaksanaan fungsi auditing. Untuk itu, konsekuensi judgment haruslah menjadi tanggung jawab auditor. Setiap kegagalan akibat tidak ditempuhnya langkah-langkah yang meyakinkan sebelum mengambil putusan (judgment) atau termasuk bilamana ia memberi judgment yang keliru, harus ditanggungnya sebagai risiko tanggung jawab profesi (professional liability).

Oleh karena itu, apabila auditor tidak berhati-hati dalam menentukan pertimbangannya, kesalahan dalam pernyataan pendapat dapat saja terjadi. Haynes (1998) mengemukakan bahwa banyak faktor yang dapat mempengaruhi pertimbangan auditor khususnya dalam mengevaluasi bukti audit, di antaranya adalah preferensi klien dan pengalaman audit. Preferensi klien dalam konsep auditing terjadi apabila klien dengan jelas menyatakan suatu hasil tertentu atau perlakuan akuntansi tertentu yang diinginkan dan auditor berperilaku secara konsisten dengan keinginan klien itu. 


\section{Subyektifitas Auditor}

Manusia adalah makhluk yang dibekali dengan daya cipta, rasa dan karsa. Setiap perubahan baik perubahan lingkungan, suasana, waktu dan tempat akan memberikan pengaruh terhadap bagaimana seseorang memutuskan sesuatu. Hal yang serupa juga terjadi pada auditor, auditor juga manusia. Mereka individu kompleks yang tidak hanya hidup dengan profesinya sebagai auditor saja. Mungkin mereka seorang ayah atau ibu, seorang anak, bagian dari masyarakat dan tentunya makhluk Tuhan dan bagian dari semesta. Semua itu merupakan satu kesatuan yang tidak terpisahkan, yang membentuk individu yang dinamai auditor. Walaupun semua pihak mengharapkan dia bertindak profesional sebagai auditor ketika berada dalam lingkungan kerja, namun tidak bisa dipungkiri bahwa kenyataan bahwa dia tidak hanya seorang auditor akan tetap berpengaruh terhadap apa yang dia kerjakan.

Manusia yang memiliki raga fisik bisa merasakan sakit dan lelah. Manusia yang dibekali dengan perasaan tentunya juga bisa merasa bahagia, sedih, gelisah dan sebagainya. Kombinasi antara fisik dan perasaan tentu saja akan mempengaruhi bagaimana proses otak berfikir dan menghasilkan suatu keputusan. Selain itu proses kehidupan yang individu jalani akan memberikan dampak terhadap pola pikir dan sikap seseorang. Oleh sebab itu wajar jika pertimbangan auditor yang dibuat oleh auditor yang sama, kasus yang sama akan menghasilkan keputusan yang berbeda pada situasi dan kondisi berbeda yang dialami oleh si auditor. Bahkan Wedemeyer (2010) menyatakan bahwa judgment audit adalah sesuatu yang unik, yang berbeda satu sama lain tergantung pada individu pembuatnya. Namun dalam tulisannya Wedemeyer juga menyebutkan bahwa hal itu menjadi petaka bagi auditor ketika pihak lain mulai membandingkan judgment yang satu dengan yang lainnya.

Lebih jauh lagi sifat manusiawi seorang auditor banyak memberikan pengaruh pada cara pandangnya terhadap suatu permasalahan yang dihadapi. Kita akan memberikan reaksi yang berbeda ketika anak kita merengek meminta mainan dan ketika yang merengek tersebut anak tetangga atau anak kecil lainnya yang tidak memiliki hubungan kerabat dengan kita. Hal serupa dapat juga terjadi pada auditor ketika klien yang dia audit memiliki hubungan dekat dengan dirinya, atau yang biasa kita sebut sebagai konflik independensi. Barnes dan Huan (1993) menyebutkan bahwa pemberian opini tergantung pada kompetensi dan independensi. Meskipun dalam standar umum kedua jelas dinyatakan bahwa dalam semua hal yang berhubungan dengan perikatan, independensi dalam sikap mental harus dipertahankan oleh auditor, namun rasa subjektifitas auditor sangat sulit dihilangkan., kembali lagi pada permasalahan awal, auditor juga manusia.

Mengapa saat ini auditor judgment menjadi salah satu isu sentral dalam dunia audit? Saat ini judgment merupakan komponen audit yang selalu mendapat kritik dari pihak di luar profesi audit (Wedemeyer, 2010). Tidak bisa kita pungkiri bahwa ada sisi lain di luar bukti audit yang turut andil ketika auditor mengambil keputusan, 
dalam hal ini adalah auditor judgment. Namun bagaimana proses pertimbangan itu dibuat hal itu tidak pernah muncul dalam opini audit. Hal itulah yang menyebabkan pengguna laporan audit menjadi sangsi apakah pertimbangan itu dibuat sebagaimana mestinya. Namun masih oleh peneliti yang sama disampaikan, betapapun besarnya kritikan terhadap pertimbangan auditor, hal ini merupakan salah satu yang terpenting dari proses pembuatan opini.

\section{Auditor Judgment dan Opini}

Dalam SA seksi 230 (tentang Penggunaan Kemahiran Profesional dengan Cermat dan Seksama dalam Pelaksanaan Pekerjaan Auditor) paragraf 10 disebutkan bahwa pertimbangan diperlukan dalam menafsirkan hasil pengujian audit dan penilaian bukti audit (IAPI, 2011). Lebih lanjut dalam paragraf yang sama juga disebutkan bahwa kesalahan dan kekeliruan dalam pertimbangan dapat terjadi, mengingat penyajian akuntansi berisi estimasi akuntansi, pengukuran yang mengandung ketidakpastian bawaan dan tergantung pada hasil dari peristiwa di masa depan. Jelas sekali dalam SA tersebut dijelaskan bahwa pertimbangan auditor diperlukan dalam memutuskan hasil audit dan dalam hal ini adalah opini. Penelitan Wedemeyer (2010) membuktikan bahwa kualitas pertimbangan auditor mempengaruhi kualitas opini audit dan berpengaruh terhadap meningkatnya kepercayaan stakeholder terhadap profesi audit.

Penelitian tentang penggunaan auditor judgment dalam proses pembuatan opini juga dilakukan oleh Schmutte dan Duncan (2009). Mereka menyajikan berbagai macam keadaan yang bisa saja muncul dalam proses audit dan merekomendasikan penggunaan judgment untuk pengambilan keputusan. Dalam penelitian tersebut, judgment sangat diperlukan terutama terkait dengan pergantian aturan maupun standar. Penelitian mereka yang bersetting di Amerika Serikat mencotohkan perubahan U.S GAAP menjadi IFRS menyulitkan auditor dalam menentukan kebergunaan informasi dalam proses audit. Oleh sebab itu auditor disarankan menggunakan pertimbangan profesionalnya sebagai alat pengambilan keputusan. Hal yang serupa memungkinkan untuk di implementasikan di Indonesia yang sedang melakukan konvergensi IFRS.

Penelitian lainnya terkait dengan penggunaan pertimbangan auditor dalam penentuan opini juga dilakukan oleh Moore (2009). Moore berpendapat bahwa semakin beragamnya undang-undang, standard setting, dan perkembangan prinsip dan standar akuntansi, penggunaan pertimbangan auditor semakin dibutuhkan dalam pengambilan keputusan audit. Bahkan Moore juga menyatakan bahwa penggunaan pertimbangan auditor memungkinkan proses audit berjalan lebih efektif dan efisien, sebab auditor hanya akan fokus terhadap hal-hal yang menurut pertimbangan profesionalnya merupakan area yang penting. Namun dalam penelitiaannya, Moore (1999) juga menyampaikan bahwa banyak sekali tantangan yang dihadapi oleh 
auditor dalam penggunaan pertimbangan profesional dalam pengambilan keputusan. Oleh sebab itu dukungan kertas kerja mutlak diperlukan sebagai alat bukti ketika ada tuntutan hukum atas pertimbangan yang telah dibuatnya.

Penelitian Ion, Munteanu, Nisculescu, Zuca (2010) mengaitkan antara professional judgment dengan materialitas dan efeknya terhadap hasil audit. Penelitian tersebut membandingkan beberapa aturan penentuan materialitas yang dikeluarkan oleh KAP Big Four dan Non Big Four, jurnal-jurnal ilimiah dan beberapa buletin akuntansi di dunia. Dalam penelitian tersebut dijelaskan bahwa ada beragam cara dan dasar dalam menentukan tingkat materialitas yang dapat dipilih oleh auditor. Perbedaan materialitas jelas akan mempengaruhi opini audit. Bisa saja seorang audit memberikan opini wajar tanpa pengecualian dan auditor lainnya memberikan opini wajar dengan pengecualian terhadap satu laporan keuangan yang sama akibat perbedaan nilai materialitas. Oleh sebab itu, dalam penelitian Ion, Munteanu, Nisculescu, Zuca (2010) menyarankan penggunaan pertimbangan profesional auditor dalam memilih tingkat materialitas.

\section{Pengalaman dan Judgement}

Beberapa penelitian mengaitkan pertimbangan auditor dengan pengalaman. Koroy (2005) dalam penelitiannya mengemukakan bahwa auditor yang kurang berpengalaman mempunyai kecenderungan yang lebih tinggi dalam menghapuskan persediaan dibandingkan auditor yang berpengalaman. Dalam penelitiannya Koroy (2005) menggunakan metode eksperimen yang melibatkan 64 auditor dari Big 4 dan non Big 4. Penelitian ini tidak menempatkan auditor pada kondisi riil dan komplek. Auditor hanya dihadapkan pada pemberian informasi disconfirming kemudian diminta untuk menetukan pilihannya terhadap preferensi klien. Jelas pada kenyataan di lapangan yang dihadapi oleh auditor lebih kompleks. Penelitian Ho (1994) juga menggunakan metode eksperimen untuk menguji hubungan pengalaman dan judgment audit. Penelitian tersebut hanya memberikan gambaran kualitatif tersbatas dan nilai $z$ score pada subjek eksperimen. Kemudian mereka diminta untuk menentukan kelangsungan hidup perusahaan yang dijadikan objek ekperimen. Sedangkan pada kenyataan, kami, para auditor, tidak semudah itu menentukan sebuah perusahaan going concern atau tidak. Kami harus menganalisa kondisi ekonomi global, langkah-langkah internal manajemen perusahaan dan lain sebagainya.

Menurut Jenkins, 1998 pertimbangan (judgment) auditor dapat menjadi bias terhadap perlakuan akuntansi yang dipreferensikan klien tersebut karena auditor dibayar oleh klien dan ingin memberikan kepuasan kepada kliennya untuk mempertahankan bisnisnya. Di lain pihak, auditor dihadapkan pada kemungkinan perkara hukum yang akan timbul seperti, kehilangan reputasi dan sanksi dari organisasi profesi yang dapat menetralkan bias tersebut. Oleh sebab itu auditor perlu meningkatkan pengetahuan dan jam terbangnya untuk menghasilkan pertimbangan yang tepat. 
Mau tidak mau auditor perlu menggali pengetahuan melalui berbagai sumber. Ilmu pengetahuan tidak hanya dari buku yang kita baca. Menurut Montaque (1953), dalam mempersenjatai dirinya dengan pengetahuan tentang objek informasi yang diauditnya, auditor perlu mengenali berbagai sumber pengetahuan yang beraneka ragam, seperti authoritarianism yang bisa diartikan pengetahuan yang didasarkan pada keyakinan terhadap sumbernya karena tingkat persuasinya yang memadai. Kemudian mysticism atau biasa dikenal dengan intuisi, imajinasi, dan pengalaman. Selain itu ada rationalism, yaitu pengetahuan yang didasarkan pada kemampuan berpikir secara logis. Pragmatism, yaitu pengetahuan yang didasarkan pada kenyataan tentang apa yang betul-betul berlangsung dengan efektif dan yang terakhir adalah empiricism.

\section{Moral Auditor dan Judgement}

Penelitian Koroy (2005) memang membuktikan bahwa auditor dengan jam terbang yang tinggi cenderung mampu membuat judgment yang tepat dibandingkan auditor yang kurang berpengalaman. Namun bagaimana dengan kasus Enron yang telah meruntuhkan Arthur Andersen? Apakah hal itu sebuah pengecualian? Skandal Enron yang merupakan white collar crime justru melibatkan auditor pada level partner. Tidak bisa dipungkiri bahwa moral seseorang sangat mempengaruhi keputusan yang dia buat. Penelitian Johari, Sanusi, Rahman dan Omar (2010) membuktikan bahwa komponen intesitas moral auditor mempengaruhi pembentukan persepsi, judgment dan keputusan auditor keputusan auditor dalam mengahadapi dilema etis.

Faktor moral inilah yang salah satu hal yang menyebabkan auditor dengan pengalaman dan jam terbang sama, dihadapkan pada kasus yang sama pula, namun bisa menghasilkan judgment yang berbeda. Pertimbangan adalah hasil pemikiran yang tentu saja sangat bergantung dari tujuan si pemikir itu sendiri. Pertimbangan auditor yang memiliki tujuan selaras dengan tujuan audit tentu saja tidak bisa disamakan dengan auditor dengan tujuan mempertahankan klien. Namun auditor yang memiliki integritas moral yang tinggi akan berusaha untuk menjaga pemikirannya untuk tetap profesional.

\section{SIMPULAN}

Auditor Opinion Judgment, berawal dari pertimbangan layak tidaknya sebuah periktan diterima. Pada tahap selanjutnya auditor kembali diminta menggunakan pertimbangan profesionalnya untuk mengukur setinggi apakah tingkat risiko pengendalian, bawaan dan deteksi yang akan dihadapi. Dengan pertimbangan profesionalnya pula auditor diminta untuk mentukan tingkat materialitas. Ketika proses perencanaan selasai, auditor masih diminta untuk menggunakan pertimbangan profesionalnya untuk menentukan sampel yang diambil. Dengan pertimbangan profesional 
pula auditor harus menganalisa apakah sebuah bukti kompeten atau tidak. Tidak cukup sampai disitu, auditor dengan menggunakan pertimbangan profesionalnya harus memutuskan perlu tidaknya menyarankan adjustment. Terakhir, auditor dengan pertimbangan profesionalnya harus memutuskan opini apa yang tepat untuk klien.

Serangkaian tahapan yang panjang melibatkan suatu pertimbangan. Kembali pada makna harfiah dari pertimbangan yang melibatkan sebuah subyektivitas pembuatnya, maka jelaslah opini didasarkan pada hal subyektif yang telah terdeferensiasi secara subyektif berkali-kali. Subyektivitas melibatkan banyak hal baik yang mampu ataupun tidak didefinisikan. Subyektivitas auditor (manusia) melibatkan rasa, lingkungan, waktu, pendidikan, masa lalu, kondisi fisik, kondisi ekonomi, kondisi mental, kondisi spiritual, dan hal-hal lainnya. Mungkin hanya adala empat macam opini yang dapat dipilih aoleh auditor, namun ada ratusan bahkan mungkin ribuan pertimbangan yang berbeda dalam proses pembuatannya untuk satu kasus klien yang sama. Dengan demikian, obyektivitas dalam sebuah pertimbangan, selama pembuatnya masih bernama manusia, hanyalah kata yang tidak kongkret. Demikian pula sebuah pertimbangan yang subyektif tidak selalu berarti ketidakprofesionalan. Selama sebuah pertimbangan didasarkan pada akal sehat dan hati nurani yang luhur, maka itulah sebuah professional judgments.

\section{DAFTAR PUSTAKA}

Alim, N., Trisni, H., dan Lilik, P. 2007. Pengaruh Kompetensi dan Independensi Terhadap Kualitas Audit dengan Etika Auditor Sebagai Variabel Moderasi. Simposium Nasional Akuntansi X.

Arens, A., and James, L. 2000. Auditing: An Integrated Approach. 8th edition. Ney Jersey: Prentice-Hall.

Barnes, P., and H.D. Huan. 1993. The Auditor Going Concern Decision: Some UK Evidence Concerning Independence and Competence. Journal of Business Finance and Accounting. January, 213-228.

Butera, A. 2011. Critical Thinking a Vital Component in Sound, Effective Audit Judgment. Protiviti's Knowledge Leader. in press.

Campbell, D., and James, H. 2005. Ethics and Auditing. Australian National University Epress. Australia.

Duh, R., Janie, C., and Elaine, C. 2006. Accountability, Task Charecterisitc and Audit Judgments. The International Journal of Accounting Studies. Special Issue, pp. 51-75.

Eisenhardt, K.M. 1989. Building theories from case study research. Academy of Management Review 14(4): 532-550.

Faisal. 2007. Investigasi Tekanan Pengaruh Sosial dalam Menjelaskan Hubungan Komitmen dan Moral Reasoning Terhadap Keputusan Auditor. Prosiding Simposium Nasional Akuntansi X. http://google.com. 23 November 2012.

Fearnley, S., Vivien, B., and Richard, B. 2005. Auditor independence and audit risk: a reconceptualisation. Journal of International Accounting Research. Vol.4(1):3971. 
Haynes, C., Jenkins, G., and S.R. Nutt. 1998. The Relationship between Client Advocacy and Audit Experience: An Exploratory Analysis. Auditing: A Journal of Practice \& Theory. Vol.17 (2) Fall, 88-104.

Ho, J. 1994. The Effect of Experience on Consensus of Going-Concern Judgments. Behavioral Research in Accounting. Vol. 6.

Ikatan Akuntan Indonesia. 2012. Standar Akuntansi Keuangan. Jakarta: Penerbit Salemba Empat.

Institut Akuntan Publik Indonesia. 2011. Standar Profesional Akuntan Publik. Jakarta: Penerbit Salemba Empat.

Ion, C., Munteanu, V., Nisculescu, M., and Zuca, M. 2010. Audit Risk, Materiality and the Professional Judgment of the Auditor. ICBA-10. In press.

Iyer, V.M., and Rama, D. 2004. Clients' Expectations on Audit Jugments: ANote. Behavioral Research In Accounting 16:63-74.

Januarti, I. 2011. Analisis Pengaruh Pengalaman Auditor, Komitmen Profesional, Orientasi Etis dan Nilai Etika Organisasi Terhadap Persepsi dan Pertimbangan Etis. Simposim Nasional Akuntansi XIV.

Jenkins, James, G. 1998. The Influence of a Client Preference on Auditor Judgment: An Investigation of Temporal Effects and Clienttrustworthiness. http://google.com. 23 November 2012.

Johari, S., Rahman, dan Omar. 2010. Moral Intensity and Ethical Decision-Making of Auditing Profession. http://sagepublications.com. 22 November 2012.

Kaplan, Steven. 2001. Ethically Related Judgments by Observers of Earnings Management. Journal of Business Ethics. 32(4):285-98.

Khomsiyah, dan Nur, I. 1998. Pengaruh Orientasi Etika terhadap Komitmen dan sensitivitas Etika auditor Pemerintah di DKI Jakarta. Jurnal Riset Akuntansi Indonesia. Vol.1(1).13-28.

Koes, S., dan Indira, J. 2010. Pengaruh Pengalaman, Keahlian, Situasi Audit, Etika dan Gender terhadap Ketepatan Pemberian Opini Auditor melalui Skeptisisme Profesional Auditor (Studi Kasus Pada KAP Big Four di Jakarta). Simposium Nasional Akuntansi XIII.

Komalasari, A. 2004. Analisis Pengaruh Kualitas Auditor dan Proxy Going Concern terhadap Opini Auditor. Jurnal Akuntansi dan Keuangan. Vol. 9 No. 2:1-16.

Konrath, L. 2001. Auditing Concepts and Apllications, A Risk-Analysis Approach. 5th Edition, South Western.

Koroy, T.R. 2005. Pengaruh Preferensi Klien dan Pengalaman Audit terhadap Pertimbangan Auditor, Simposium Nasional Akuntansi VIII. 917-928.

Laily, N. 2010. Pengaruh Pengalaman Auditor terhadap Ethical Judgment Dengan Pengetahuan Auditor dan Komitmen Profesi sebagai Variable Intervening. Tesis. Program Pasca Sarjana Fakultas Ekonomi Universitas Brawijaya.

Lehman, G. 2004. Accounting, Accountability and Religion: Charles Taylor's Catholic Modernity and the Malaise of a Disenchanted World. Fourth Asia Pacific Interdisciplinary Research in Accounting Conference

Manao, H. 2007. Filosofi Auditing. Edisi Kedua. Bogor: Pusdiklatwas BPKP.

Mautz, R.K., and Hussen, S. 1993. The Philosophy of Auditing. American Accounting Association. Sarasota FL. 
Mayangsari, S. 2003. Pengaruh Keahlian dan Independensi Terhadap Pendapat Audit: Sebuah Kuasieksperimen. Jurnal Riset Akuntansi Indonesia. Volume 6 No. 1 Edisi Januari.

Montague, W.P. 1953. The Ways of Knowing. New York: The Macmillan Company.

Moore, G. 1999. Using Professional Judgment. The Auditor's Report. Vol. 33 No 1.

Mulyaningsih, N., dan Budiyanto, T. 2006. Pengujian Variabel-Variabel yang Berpengaruh Terhadap Keinginan Klien untuk Mempengaruhi Kebijakan Audit. Simposium Nasional Akuntansi IX.

Pratolo, S. 2007. Good Corporate Governance dan Kinerja Bumn di Indonesia: Aspek Audit Manajemen dan Pengendalian Intern sebagai Variabel Eksogen serta Tinjauannya pada Jenis Perusahaan. Simposium Nasional Indonesia X.

Pricewaterhouse Coopers. 2009. Auditing Risk Culture, Art or Science? www. pricewa ter housecoopers.com. 15 Maret 2013.

Rahmiati, dan Indra, W.K. 2004. Hubungan antara Mentoring dengan Role Stress dan Job Outcomes dalam Lingkungan Akuntan Publik. Simposium Nasional Akuntansi VII. 1634-1661.

Schmutte, J., and James, D. 2009. Professional judgment: a model for accounting and auditing decisions. The CPA Journal. September 1.

Skandal Enron. (n.d). http://www.wikipedia.com. 7 Januari 2012.

Suraida, I. 2005. Pengaruh Etika,h Kompetensi, Pengalaman Audit Terhadap Risiko Audit Terhadap Skeptisme Profesional Auditor Dan Ketetapan Pemberian Opini Akuntan Publik, Sosiohumaniora, Volume 7 No. 3.

Tamtomo, D.S. 2008. "Faktor-Faktor yang Menentukan Opini Audit". ORBITH. Vol. 4 No. 3 , Nopember : 448-452.

Wedemeyer, P. 2010. A Discussion of Auditor Judgment as The Critical Component in Audit Quality - A Practitioner's Perspective. International Journal of Disclosure and Governance, in press. 